\title{
Tools to assess the quality of life in patients with Parkinson's disease: a systematic review
}

Anna Berardi , Erik Regoli , Marco Tofani , Donatella Valente , Giovanni Fabbrini , Andrea Fabbrini , Marcello Ruggieri , Francescaroberta Panuccio \& Giovanni Galeoto

To cite this article: Anna Berardi , Erik Regoli , Marco Tofani , Donatella Valente , Giovanni Fabbrini , Andrea Fabbrini , Marcello Ruggieri, Francescaroberta Panuccio \& Giovanni Galeoto (2020): Tools to assess the quality of life in patients with Parkinson's disease: a systematic review, Expert Review of Pharmacoeconomics \& Outcomes Research, DOI: 10.1080/14737167.2021.1841638

To link to this article: https://doi.org/10.1080/14737167.2021.1841638

Accepted author version posted online: 22

Oct 2020.

Submit your article to this journal $\square$

Q View related articles ๘

View Crossmark data $[\pi$ 
Tools to assess the quality of life in patients with Parkinson's disease: a systematic review

Anna Berardi ${ }^{1}$, Erik Regoli ${ }^{2}$, Marco Tofani ${ }^{3}$, Donatella Valente ${ }^{1,4}$, Giovanni Fabbrini ${ }^{1,4}$, Andrea

Fabbrini $^{4}$, Marcello Ruggieri ${ }^{5}$, Francescaroberta Panuccio ${ }^{2}$ and Giovanni Galeoto ${ }^{1}$

${ }^{1}$ Department of Human Neurosciences, Sapienza University of Rome, Viale dell' Università, 30, 00185,

Rome, Italy.

${ }^{2}$ Sapienza University of Rome, Piazzale Aldo Moro, 5, 00185, Rome, Italy.

${ }^{3}$ Department of Neurorehabilitation and Robotics, Bambino Gesù Paediatric Hospital, Vatican City

${ }^{4}$ IRCCS Neuromed, Via Atinense, 18, 86077 Pozzilli, IS, Italy.

${ }^{5}$ Santa Lucia Foundation IRCCS, Via Ardeatina, 306/354, 00179 Rome, Italy

\section{*Corresponding author:}

Galeoto Giovanni,

Address: Viale dell'Università, 30, 00185 Rome

Email: giovanni.galeoto@uniroma1.it

Phone number: 3271431083 


\begin{abstract}
Introduction. The clinical, social, and economic implications of Parkinson's disease (PD) are significant; disability occurs leading to a low quality of life (QoL). Information on the QoL of patients with PD and studies on the relationship between QoL and motor and cognitive function are necessary for both research and clinical use to make informed decisions in healthcare and rehabilitation. The aim of this study was to determine which scales are most used to assess QoL in patients with PD.
\end{abstract}

Area covered. A literature search was conducted in MEDLINE, Scopus, CINAHL, PsycINFO, and Web of Science. Two authors independently identified eligible studies based on predefined inclusion criteria and extracted the data. Study quality and the risk of bias were assessed using the COSMIN checklist.

Expert opinion. 116 suitable studies were included, and 42 different instruments were identified. The most frequently used scales were the 39-items and 8-items Parkinson's Disease Questionnaire (PDQ-39) (PDQ-8). These findings suggest further investigation of existing PD outcome measures would benefit patients, researchers, and clinicians. Validated, universal outcome measures are required to allow comparisons across practice; therefore, we recommend that future researchers use a common set of outcome assessments based on the results of this review.

Keywords: Assessment tool; Outcome measure; Parkinson's Disease; Psychometric properties; Quality of Life; Systematic Review; Validation 


\section{INTRODUCTION}

The clinical, social, and economic implications of Parkinson's disease (PD) are significant; disability occurs due to problems associated with walking, washing, and dressing, loss of dexterity, speech difficulties, fatigue, and social and emotional problems, leading to a low quality of life (QoL) for both patients and their caregivers. Information on the QoL of patients with PD and studies on the relationship between QoL and motor and cognitive function are necessary for both research and clinical use to make informed decisions in healthcare and rehabilitation. [1-3] To identify the best treatment methods and routines for people with PD the first step is to identify the correct assessment tool to robustly assess the efficacy of interventions both at the level of the clinical treatments and in the context of clinical trials. The classic clinical trial is designed to test the efficacy of a particular intervention as compared to another intervention or a control group. Facilitating comparison between groups requires a standard measure of outcome that is relevant and suited to the clinical question, valid for the population studied, and meaningful to the research team $[4]$.

Therefore, it was decided to carry out this systematic review because clinicians and researchers need to know the most reliable, valid, and universally accepted measures currently available for evaluating people with SCIand to allow comparisons between different treatments.

the International Parkinson and Movement Disorders Society has published recommendations for the measurement of QoL in patients with PD that classify QoL as recommended, suggested, or listed. [5] Several scales have been proposed to evaluate the QoL of patients with PD; [6] in a systematic review, Martinez-Martin et al [7] classified four generic scales (i.e., the EuroQoL 5dimension instrument, Nottingham Health Profile, 36-Item Short Form Health Survey, and Sickness Impact Profile) and five specific scales (i.e., the -Item Parkinson's Disease Questionnaire (PDQ-8), Parkinson's Disease Quality of Life Questionnaire, Parkinson's Impact Scale, SCales for Outcomes 
in Parkinson's disease - (SCOPA-PS), and the 39-Item Parkinson's Disease Questionnaire (PDQ39)) as recommended. Since the study by Martinez-Martin et al. was conducted in 2011 and only included articles from the PubMed database, we decided to update this topic. The primary objective of this study was to research and describe the tools most frequently used to evaluate QoL in individuals with PD through a systematic review. The secondary objective was to describe the languages in which these tools are validated.

\section{BODY}

This study was conducted by a research group composed by medical doctors and rehabilitation professionals from the "Sapienza" University of Rome and from "Rehabilitation \& Outcome Measure Assessment" (R.O.M.A.) association. R.O.M.A. association in the last few years has dealt with several systematic reviews and the validation of many outcome measures in Italy [8-18].

\subsection{Protocol and registration}

After registration of the protocol on the International Prospective Register of Systematic Reviews (PROSPERO) website (CRD42019147041, available from: https://www.crd.york.ac.uk/prospero/display record.php?ID=CRD42019147041), this review was conducted in accordance with the 27-item Preferred Reporting Items for Systematic Reviews and Meta-Analyses (PRISMA) checklist[19,20] based on the Methodological Expectations of Cochrane Intervention Reviews (MECIR) [21,22].

\subsection{Eligibility criteria for considering studies for this review: types of studies and types of participants}

A systematic review of the English-language literature was conducted and included a search for studies that evaluated the psychometric properties of outcome measures that explored QoL in people with PD. The terms health related QoL (HRQoL), and QoL are often used interchangeably. 
Given that these are two key terms in the literature, their appropriate and clear use is important. A potential solution is to define HRQoL as the way health is empirically estimated to affect QoL or use the term to only signify the utility associated with a health state [23]. The World Health Organization (WHO) defines QoL as an individual's perception of their position in life in the context of the culture and value systems in which they live and in relation to their goals, expectations, standards and concerns [24] QoL is a broad concept that is affected in a complex way by a person's physical health, psychological state, personal beliefs, social relationships, and relationship to salient features of their environment.

All studies that evaluated the psychometric properties of a clinician's report, a patient's self-report, and/or physical performance outcome measures that measured QoL in at least one domain of the tool were included. Studies were limited to people with PD, regardless of their clinical course or the length of time since diagnosis. Studies with mixed diagnosis samples were included if a subgroup of participants could be identified and for which separate data were available. No restrictions were applied to the publication period or to the country in which the study was conducted.

\section{Inclusion criteria}

(1) Validation studies and cross-cultural adaptation studies;

(2) Studies on QoL;

(3) Studies on tests, questionnaires, and self-reported and performance-based outcome measures; and

(4) Studies with a population of patients with PD;

\section{Exclusion criteria}

(1) Trials or studies that evaluated the effectiveness of interventions in which a questionnaire was used as an endpoint (without studying the measurement properties); 
(2) Studies including measures of cognitive, motor, and other constructs without mention of QoL in any domain; and

(3) Studies with mixed diagnosis samples if a subgroup of PD participants could not be identified or did not have separate data.

\subsection{Search methods to identify the studies}

Studies were identified for inclusion through individualized systematic searches in five electronic databases. All potential studies were identified by two reviewers.

\subsection{Electronic searches}

The following electronic databases were systematically searched in July 2019: MEDLINE, CINAHL, PsycINFO (via EBSCO), Scopus, and Web of Science. The Medical Subject Headings (MeSH) of the United States National Library of Medicine were used to find the terms to be included in the search strategy. The MeSH terms used were Parkinson's disease, quality of life, and validation; these terms resulted in the search strategy which was built for MEDLINE and adapted for the other databases.

\subsection{Study selection}

Before starting the review, duplicate articles were filtered using Microsoft Excel. Following the guidelines of the PRISMA checklist[19], two reviewers (ER and GG) first independently screened the titles, keywords, and abstracts. After the first screening, the primary reviewer (ER) selected the relevant studies and assessed them using the following inclusion criteria: published quantitative studies that evaluate the psychometric properties of the outcome measures and then the validations of scales on the quality of life only if inherent to PD. Then, a second reviewer cross-checked the studies. After the second screening, studies that did not fit the inclusion criteria were systematically excluded, and others that appeared pertinent were identified. A final list of studies that were eligible for inclusion was compiled, and any disagreements were resolved by a third reviewer or by 
consensus. The full text versions of studies that met the criteria were reviewed to determine whether they should be included in the review.

\subsection{Data collection and data extraction}

The approach to data collection and extraction was chosen based on the Cochrane methods [25]. Two reviewers independently extracted the demographics and descriptive information from the studies, and each study was keyworded for generic issues such as language, country, focus, and population. These characteristics were judged based on the information provided in the reports in the studies. Moreover, reviewers followed the recommendations from the COnsensus-based Standards for the selection of health Measurement Instruments (COSMIN) initiative [26,27]. The outcome measures reported in each publication were recorded and categorized for comparison. The authors decided to report the following psychometric characteristics: Cronbach's alpha for internal consistency, the intraclass correlation coefficient for stability, and Pearson's correlation for validity. The aspects of validity were defined, and a checklist was used to determine which aspects had been evaluated.

\subsection{Quality assessment}

The studies' content and methodology were qualitatively analyzed. The methodological quality of each of the selected studies was assessed using the COSMIN checklist [26,27], a quality assessment tool for observational cohort and cross-sectional studies. The COSMIN checklist proposes ten consecutive steps, of which those from 5 to 8 evaluate the quality of the studies by evaluating measurement properties. Eight measurement properties are considered, and their presence and adequacy in the studies is verified (with an assignment of "+" when adequate, "?" when some information is missing, and "-" when inadequate). To define the quality of the studies, a score from 0 to 8 is given to each study.

\section{CONCLUSION}

\section{Study selection}


The research first identified 2160 matches. After the removal of duplicates, there were 1323 unique articles. The remaining studies were re-checked to remove irrelevant studies. A total of 847 studies did not concern QoL in individuals with PD, and 267 were not scale validations. The remaining 209 studies were selected for full text review. A flowchart summarizing the study selection is shown in Figure 1.

\subsection{Excluded studies}

After reading the full text versions of the articles, we excluded 93 studies: 45 that were not validations, 29 that did not concern QoL, and 19 that did not concern PD.

\subsection{Included studies}

After the application of the inclusion and exclusion criteria, the review included 116 different studies on the validations of scales that measure QoL in PD. Among these, 42 different assessment tools on the QoL of people with PD that were internationally validated were identified. Table 1 reports all assessment tools measuring QoL in patients with PD.

\subsection{Study characteristics}

All the studies were cross-sectional, psychometric studies. The sample size in the studies varied from $24[28]$ to $537[29]$. The majority of the participants were in their mid to late $60 \mathrm{~s}$, and their mean age ranged from 47.9 years[30,31] to 72 years[32]. The most commonly used tools were the PDQ-39; 8-Item Parkinson's Disease Questionnaire (PDQ-8); SCOPA-PS; SCales for Outcomes in Parkinson's disease - Sleep (SCOPA-Sleep); Parkinson's Disease Sleep Scale-2 (PDSS-2); and Parkinson's Fatigue Scale (PFS).

\subsection{PDQ-39}

PDQ-39 is a scale that has been validated in multiple languages. It was created in English in 1997 by C. Jenkinson and has been validated in Swedish[33], Portuguese[34,35], Spanish[36], Filipino[37], American English[38], Greek[39], Italian[40], Chinese (Beijing)[41], Chinese 
(Taiwan)[42], Korean[43], Estonian[44], Chinese (Singapore)[45], English (Singapore)[46], Chinese (mainland China)[47], English (online)[48], Danish[49], Serbian[50], Spanish (Ecuador) [51], French[52], German[53], and Japanese[54]. PDQ-39 is a specific scale for patients with PD that assesses their QoL in eight domains: mobility, daily activities, emotional well-being, stigma, social support, knowledge, communication, and physical discomfort. QoL is assessed on a 5-point scale for each of the 39 questions as follows: $0=$ Never; $1=$ Rarely; $2=$ Sometimes; $3=$ Often; and 4 = Always. The minimum score is 0 (good health), and the maximum score is 100 (bad health); a higher score corresponds to lower QoL. The results obtained in the published validations indicate that the PDQ-39 has discrete internal consistency, with a Cronbach's $\alpha$ value that varied from 0.33 to 0.98 . Cronbach's $\alpha$ was less than 0.70 in 13 studies but only for some scale domains. The Intraclass Correlation Coefficient (ICC) values ranged from 0.34 to 0.96 . The ICC was less than 0.70 in only five studies, indicating that the scale had good reliability. The validation data are shown in Table 2.

\subsection{PDQ-8}

The second scale by the number of validations was the PDQ- 8 , which was validated by Jenkinson in 1996; it has been validated in English[55], Japanese[56], Chinese[57], Turkish[58], Persian[59], Italian[32], English (Singapore) [46], and Greek[60]. The domains analyzed in the scale are the same as those of the PDQ-39 but there is only a single question for each domain in the PDQ-8. A value from 0 to 4 is assigned to each question on the scale, and a total score ranging from 0 (good health) to 100 (bad health) is obtained. The results showed that the scale has good internal consistency, with a Cronbach's $\alpha$ value ranging from 0.56 to 0.94 . The alpha value was less than 0.70 only in one domain of the scale of one of the studies analyzed. The ICC values showed greater variability, ranging from 0.24 to 0.983 . The ICC value was less than 0.70 in only three studies. The validation data are shown in Table 3.

\subsection{SCOPA-PS}


The development of SCOPA-PS was part of a larger research project. The SCOPA, which are short, practical, and clinimetrically safe scales, were selected or developed for all relevant domains of PD. The SCOPA-PS consists of 11 elements and focuses on the evaluation of the psychosocial aspects of the life of a patient with PD and has been validated in French[61], Spanish[62], Persian[63], Spanish (Latin-America)[64], Brazilian Portuguese[34], and Danish[65]. The scale has a high internal consistency, with a Cronbach's $\alpha$ value varying from 0.83 to 0.93 . The ICC varied from 0.43 to 0.99 . The data are shown in Table 4.

\subsection{SCOPA-Sleep}

The SCOPA-Sleep has two sub-scales: one concerning nighttime sleep and one concerning daytime fatigue. The first consists of five elements that evaluate difficulty falling asleep, fragmentation of sleep, sleep duration, early waking, and the feeling of having slept little. The second includes six elements that evaluate the frequency at which the patient falls asleep in certain situations. The SCOPA-Sleep has been validated in German[66], Korean[67], Swedish[68], Spanish[69], and Danish[70]. Cronbach's alpha ranges from 0.801 to 0.880 , indicating good internal consistency. The corresponding data are shown in Table 4.

\subsection{PDSS-2}

The PDSS-2 is an update of the previous PDSS with modifications to 6 of the 15 questions. It is composed of 15 questions on various sleep and nocturnal disturbances that are evaluated by patients as one of five answers, from 0 (never) to 4 (very frequent). The total PDSS- 2 score ranges from 0 (no disturbance) to 60 (maximum night disturbance). The scale has been validated in German[71], Hungarian[29], Spanish[69], Italian[72], and Japanese[73]. The PDSS-2 has both excellent internal consistency (Cronbach's $\alpha$ from 0.730 to 0.863$)$ and good ICC (0.800 to 0.943$)$. The corresponding data are shown in Table 5.

\subsection{PFS}


PFS was created in English in 2004 by R.G. Brown et al.[74]. The objectives were to develop a valid and reliable measure of fatigue that resulted from the personal experiences of people with PD, that had minimal overlap with other motor and non-motor symptoms of PD, and that was practical for use in the clinic[74]. The scale, which consists of 16 questions, has been validated in Turkish[75], Chinese[76], Greek[77], and Spanish[78]. The Cronbach's $\alpha$ value ranges from 0.930 to 0.974 , showing excellent internal consistency, while the ICC varies from 0.50 to 0.93 . The corresponding data are shown in Table 6.

\subsection{Other scales}

The search retrieved 36 other validated tools. The validation data are presented in Table 6.

\subsection{Risk of bias}

The risk of bias in the included studies was mixed. The methodological quality of each of the selected studies was assessed using the COSMIN checklist[26]. The quality scores from the responsiveness subset of questions of the COSMIN checklist are reported in Table 7. In general, the studies were fairly good quality.

\section{EXPERT OPINION}

The implications of PD are significant for QoL, since this disease worsens the motor and non-motor function of individuals. The problems include issues with walking, washing, and dressing, loss of dexterity, speech difficulties, fatigue, and social and emotional problems. To improve the patient's QoL, it is necessary to measure their QoL. Therefore, the primary objective of this study was to research and describe the tools most frequently used to evaluate QoL and/or aspects of it, such as sleep quality, in patients with PD using a systematic review. The secondary objective was to evaluate the languages in which these tools have been validated and their methodological quality.

It is evident that the PDQ-39 has the highest number of international validations and that it is available in many languages. The results suggest that this scale is reliable. None of the studies 
reported cutoff values for the scale. In future studies, it would be useful to investigate these values to define different ranges of QoL (i.e., poor, moderate, and good).

The second most frequently used scale is the PDQ-8, which is internationally available in eight languages. Like the PDQ-39, it has excellent psychometric qualities, which makes it valid and reliable.

There are also other tools that have been validated to assess QoL in patients with PD. These tools include the Parkinson's Disease Quality of Life questionnaire (PDQL). This is a self-administered questionnaire that has 37 questions, which are divided into four sub-scales: parkinsonian symptoms, systemic symptoms, social functioning, and emotional functioning. An overall score is obtained, and a higher score indicates a better perceived QoL[79].

Another specific tool to assess the QoL in patients with PD is the Parkinson Impact Scale (PIMS), which is a short and practical 10-element tool; however, the scale has only been validated in three languages [80].

The European Quality of Life Questionnaire 5-level version (EQ-5D-5L) is also a scale for QoL, but it is not specific for patients with PD. It includes a five-dimensional questionnaire (EQ-5D-5L) and a visual analog score (EQ-VAS). The EQ-5D-5L assesses mobility, self-care, daily activities, pain and discomfort, and anxiety and depression. Each article was evaluated using a five-point Likert scale as follows: $1=$ No problem, $2=$ Mild, $3=$ Moderate, $4=$ Serious, and $5=$ Extreme[81]

Another scale on QoL, which emerged from the review, is the WHO QoL[82]. It is not specific for patients with PD composed of six aspects: sensory skills; autonomy; past, present, and future activities; social participation; (thoughts on) death; and intimacy. Neuroquality of life (Neuro-qol), a scale created specifically to assess neurological diseases and validated for PD, emerged among the research results. This scale includes 13 groups of questions (a series of questions covering a single 
construct) that address issues common in many neurological diseases and those most relevant to certain diseases. These groups of questions evaluate mental, physical, and social well-being[83].

In addition to the scales that evaluate QoL as a whole, various scales have also emerged that focus on a series of aspects or on a single factor that affects QoL. Previously, the psychometric properties of SCOPA-PS, SCOPA-Sleep, PDSS-2, and PFS, which evaluate the psychosocial component of PD, sleep problems, and the incidence of fatigue in the QoL, respectively, have been analyzed. In addition to these scales, we found scales on the impact of autonomic system dysfunction $[84,85]$ (in particular, systematic research identifying specific scales for dysphagia in patients with $\mathrm{PD}[86])$, on problems related to the risk of falling[79,80] and the phenomenon of freezing[87], on cognitive factors[88] (specifically, on apathy[89] and depression[90] and validated in patients with PD), and on the influence of pain on QoL[91].

There are some limitations to this review that need to be considered. While we systematically searched five electronic databases, it is possible that not all relevant studies were identified. The studies may have been published in journals that were not covered by the databases. In addition, this review only included published studies. Therefore, studies that have been submitted and not accepted for publication or that have only recently been accepted for publication were excluded. Therefore, it is possible that this systematic review is not a complete representation of the evidence available worldwide.

The data presented in the literature up to October 2019 permitted the identification of 42 QoL assessment tools in patients with PD. Many of the tools identified are specific for the evaluation of a single domain of QoL. Internationally, the instruments with the most validations are the PDQ-39 and PDQ-8. The PDQ-39 has been validated in 15 languages and uses 39 questions divided into eight domains to evaluate the QoL in patients with PD, whereas the PDQ-8 uses eight questions, one for each domain. They are both psychometrically valid and reliable scales. This systematic review has highlighted a strong heterogeneity of validated tools among the various national contexts 
can be seen, moreover, The many tools available show the tendency for new scales to be created. This heterogeneity can be assumed to have a positive meaning if one thinks about the multiple needs of the clinical context, but certainly leads to the need to make the tools more suitable for various cultural contexts. These findings suggest further investigation of existing outcome measures would benefit patients, researchers, and clinicians. Universal, validated outcome measures are needed to allow comparisons across practice. Therefore, we recommend that future researchers use a common set of outcome assessments based on the results of this review. Building an international consensus in this area will ensure an improvement in the quality of care, rehabilitation and efficiency of health care systems.

\section{Funding}

This paper was not funded.

\section{Declaration of interest}

The authors have no relevant affiliations or financial involvement with any organization or entity with a financial interest in or financial conflict with the subject matter or materials discussed in the manuscript. This includes employment, consultancies, honoraria, stock ownership or options, expert testimony, grants or patents received or pending, or royalties.

\section{Reviewers Disclosure}

Peer reviewers on this manuscript have no relevant financial relationships or otherwise to disclose. 


\section{Availability of data and material}

The data that support the findings of this study are available from the corresponding author upon reasonable request.

\section{REFERENCES}

Papers of special note have been highlighted as either of interest $(\bullet)$ or of considerable interest $(\bullet \bullet)$ to readers.

[1] T. Yamamoto, T. Uchiyama, Y. Higuchi, M. Asahina, S. Hirano, Y. Yamanaka, L. Weibing, S. Kuwabara, Long term follow-up on quality of life and its relationship to motor and cognitive functions in Parkinson's disease after deep brain stimulation, J. Neurol. Sci. (2017). https://doi.org/10.1016/j.jns.2017.05.037.

**this study describes quality of life and its relationship to motor and cognitive functions in Parkinson's disease after deep brain stimulation

[2] V.B. Dogan, A. Koksal, A. Dirican, S. Baybas, A. Dirican, G.B. Dogan, Independent effect of fatigue on health-related quality of life in patients with idiopathic Parkinson's disease, Neurol. Sci. (2015). https://doi.org/10.1007/s10072-015-2340-9.

[3] S. Zhang, D. Liu, D. Ye, H. Li, F. Chen, Can music-based movement therapy improve motor dysfunction in patients with Parkinson's disease? Systematic review and meta-analysis, Neurol. Sci. (2017). https://doi.org/10.1007/s10072-017-3020-8.

[4] G. Galeoto, F. Iori, R. De Santis, V. Santilli, R. Mollica, M.A. Marquez, J. Sansoni, A. Berardi, The outcome measures for loss of functionality in the activities of daily living of adults after stroke: a systematic review, Top. Stroke Rehabil. (2019). https://doi.org/10.1080/10749357.2019.1574060.

**This study is a systematic review on outcome measures for loss of functionality in the activities of 


\section{daily living of adults after stroke}

[5] J. Marinus, C. Ramaker, J.J. van Hilten, A.M. Stiggelbout, Health related quality of life in Parkinson's disease: A systematic review of disease specific instruments, J. Neurol. Neurosurg. Psychiatry. (2002). https://doi.org/10.1136/jnnp.72.2.241.

[6] A. Alvarado-Bolaños, A. Cervantes-Arriaga, M. Rodríguez-Violante, R. Llorens-Arenas, H. Calderón-Fajardo, R. Millán-Cepeda, R. Leal-Ortega, I. Estrada-Bellmann, C. Zuñiga-Ramírez, Impact of neuropsychiatric symptoms on the quality of life of subjects with Parkinson's disease, J. Parkinsons. Dis. (2015). https://doi.org/10.3233/JPD-150597.

[7] P. Martinez-Martin, M. Jeukens-Visser, K.E. Lyons, C. Rodriguez-Blazquez, C. Selai, A. Siderowf, M. Welsh, W. Poewe, O. Rascol, C. Sampaio, G.T. Stebbins, C.G. Goetz, A. Schrag, Health-related quality-of-life scales in Parkinson's disease: Critique and recommendations, Mov. Disord. (2011). https://doi.org/10.1002/mds.23834.

\section{**this study reports recommendations about Health-related quality-of-life scales in Parkinson's} disease. It represents the starting point for the current study.

[8] M. Tofani, G. Galeoto, D. Cazzetta, A. Berardi, J. Sansoni, D. Valente, Validation of the Pediatric Evaluation of Disability Inventory in an Italian Population with Autism Spectrum Disorder: a CrossSectional Study, Clin. Ter. (2019). https://doi.org/10.7417/CT.2019.2176.

[9] G. Romagnoli, A. Leone, G. Romagnoli, J. Sansoni, M. Tofani, R. De Santis, D. Valente, G. Galeoto, Occupational Therapy's efficacy in children with Asperger's syndrome: a systematic review of randomized controlled trials, Clin. Ter. (2019). https://doi.org/10.7417/CT.2019.2164.

[10] V. Belluscio, E. Bergamini, M. Iosa, M. Tramontano, G. Morone, G. Vannozzi, The iFST: An instrumented version of the Fukuda Stepping Test for balance assessment, Gait Posture. (2018). https://doi.org/10.1016/j.gaitpost.2017.12.010.

[11] M. Ioncoli, A. Berardi, M. Tofani, F. Panuccio, A. Servadio, D. Valente, G. Galeoto, Crosscultural Validation of the Community Integration Questionnaire-Revised in an Italian Population, Occup. Ther. Int. (2020). https://doi.org/10.1155/2020/8916541. 
[12] A. Berardi, M. Saffioti, M. Tofani, M. Nobilia, G. Culicchia, D. Valente, A. Servadio, G. Galeoto, Internal consistency and validity of the Jebsen-Taylor hand function test in an Italian population with hemiparesis, NeuroRehabilitation. (2019). https://doi.org/10.3233/NRE-192867.

[13] M. Tofani, C. Candeloro, M. Sabbadini, D. Field, F. Frascarelli, L. Lucibello, D. Valente, G. Galeoto, E. Castelli, A study validating the Italian version of the Level of Sitting Scale in children with cerebral palsy, Clin. Rehabil. (2019). https://doi.org/10.1177/0269215519858387.

[14] M. Tofani, M. Nobilia, G. Culicchia, G. Esposito, A. Savona, I. Tashi, A. Ventura, G. Galeoto, The Italian version of rheumatoid arthritis pain scale (IT-RAPS): psychometric properties on community and clinical samples, Reumatismo. (2019). https://doi.org/10.4081/reumatismo.2019.1043.

[15] A. Amedoro, A. Berardi, A. Conte, E. Pelosin, D. Valente, G. Maggi, M. Tofani, G. Galeoto, The effect of aquatic physical therapy on patients with multiple sclerosis: A systematic review and metaanalysis, Mult. Scler. Relat. Disord. (2020). https://doi.org/10.1016/j.msard.2020.102022.

[16] M. Tramontano, G. Morone, A. Curcio, G. Temperoni, A. Medici, D. Morelli, C. Caltagirone, S. Paolucci, M. Iosa, Maintaining gait stability during dual walking task: Effects of age and neurological disorders, Eur. J. Phys. Rehabil. Med. (2017). https://doi.org/10.23736/S1973-9087.16.04203-9.

[17] M. Tramontano, E. Bergamini, M. Iosa, V. Belluscio, G. Vannozzi, G. Morone, Vestibular rehabilitation training in patients with subacute stroke: A preliminary randomized controlled trial, NeuroRehabilitation. (2018). https://doi.org/10.3233/NRE-182427.

[18] G. Castelnuovo, E.M. Giusti, G.M. Manzoni, D. Saviola, S. Gabrielli, M. Lacerenza, et al. What is the role of the placebo effect for pain relief in neurorehabilitation? Clinical implications from the Italian consensus conference on pain in neurorehabilitation, Front. Neurol. (2018). https://doi.org/10.3389/fneur.2018.00310.

[19] D. Moher, L. Shamseer, M. Clarke, D. Ghersi, A. Liberati, M. Petticrew, etal. Schünemann, I. Simera, W. Summerskill, J. Tetzlaff, T.A. Trikalinos, D. Tovey, L. Turner, E. Whitlock, Preferred reporting items for systematic review and meta-analysis protocols (PRISMA-P) 2015 statement, Rev. Esp. Nutr. Humana y Diet. (2016). https://doi.org/10.1186/2046-4053-4-1. 
[20] J. Higgins, S. Green, Cochrane Handbook for Systematic Reviews of Interventions | The Cochrane Collaboration, Cochrane Collab. (2011).

[21] J. Chandler, R. Churchill, T. Lasserson, D. Tovey, J. Higgins, Methodological standards for the conduct of new Cochrane Intervention Reviews, Http://Editorial-Unit.Cochrane.Org/Sites/EditorialUnit.Cochrane.Org/Files/Uploads/MECIR_conduct_standards\%202.3\%2002122013.Pdf. (2013).

[22] J. Chandler, R. Churchill, J. Higgins, T. Lasserson, D. Tovey, Methodological Expectations of Cochrane Intervention Reviews (MECIR), Cochrane Database Syst. Rev. (2013).

[23] M. Karimi, J. Brazier, Health, Health-Related Quality of Life, and Quality of Life: What is the Difference?, Pharmacoeconomics. 34 (2016) 645-649. https://doi.org/10.1007/s40273-016-0389-9.

[24] M.C. Cuerda, A. Apezetxea, L. Carrillo, F. Casanueva, F. Cuesta, J.A. Irles, M.N. Virgili, M. Layola, L. Lizan, Development and validation of a specific questionnaire to assess health-related quality of life in patients with home enteral nutrition: NutriQoL $®$ development, Patient Prefer. Adherence. (2016). https://doi.org/10.2147/PPA.S110188.

[25] J. Noyes, S. Lewin, Chapter 5: Extracting Qualitative Evidence, Suppl. Guid. Incl. Qual. Res. Cochrane Syst. Rev. Interv. (2011). https://doi.org/10.2307/893875.

[26] L.B. Mokkink, H.C.W. de Vet, C.A.C. Prinsen, D.L. Patrick, J. Alonso, L.M. Bouter, C.B. Terwee, COSMIN Risk of Bias checklist for systematic reviews of Patient-Reported Outcome Measures, Qual. Life Res. (2018). https://doi.org/10.1007/s11136-017-1765-4.

\section{* This is the checklist for systematic reviews of Patient-Reported Outcome Measures}

[27] C.B. Terwee, C.A.C. Prinsen, A. Chiarotto, M.J. Westerman, D.L. Patrick, J. Alonso, L.M. Bouter, H.C.W. de Vet, L.B. Mokkink, COSMIN methodology for evaluating the content validity of patientreported outcome measures: a Delphi study, Qual. Life Res. (2018). https://doi.org/10.1007/s11136018-1829-0.

\footnotetext{
* This study describes methodology for systematic reviews of Patient-Reported Outcome Measures
} 
[28] V.D. Bello-Haas, L. Klassen, S. Sheppard, A. Metcalfe, Psychometric properties of activity, selfefficacy and quality-of-life measures in individuals with parkinson disease, Physiother. Canada. (2011). https://doi.org/10.3138/ptc.2009-08.

[29] N. Kovács, K. Horváth, Z. Aschermann, P. Ács, E. Bosnyák, G. Deli, E. Pál, J. Janszky, B. Faludi, K. Karádi, I. Késmárki, M. Bokor, E. Rigó, J. Lajtos, P. Klivényi, G. Dibó, L. Vécsei, A. Takáts, A. Tóth, P. Imre, F. Nagy, M. Herceg, A. Kamondi, E. Hidasi, S. Komoly, Independent validation of Parkinson'S disease Sleep Scale 2nd version (PDSS-2), Sleep Biol. Rhythms. (2016). https://doi.org/10.1007/s41105-015-0024-8.

[30] S. Karşidağ, N. Çinar, Ş. Şahin, N. Kotevoğlu, M.F. Ateş, Validation and reliability study of the turkish version of the neuroquality of life (Neuro-qol)-stigma scale for neurological disorders, Turkish J. Med. Sci. (2019). https://doi.org/10.3906/sag-1811-50.

[31] K. Chen, Y.J. Yang, F.T. Liu, D.K. Li, L.L. Bu, K. Yang, Y. Wang, B. Shen, R.Y. Guan, J. Song, J. Wang, J.J. Wu, Evaluation of PDQ-8 and its relationship with PDQ-39 in China: A three-year longitudinal study, Health Qual. Life Outcomes. (2017). https://doi.org/10.1186/s12955-017-0742-5.

[32] F. Franchignoni, A. Giordano, G. Ferriero, Rasch analysis of the short form 8-item Parkinson's Disease Questionnaire (PDQ-8), Qual. Life Res. (2008). https://doi.org/10.1007/s11136-008-9341-6.

[33] P. Hagell, D. Whalley, S.P. McKenna, O. Lindvall, Health status measurement in Parkinson's disease: Validity of the PDQ-39 and Nottingham Health Profile, Mov. Disord. (2003). https://doi.org/10.1002/mds.10438.

[34] F.J. Carod-Artal, P. Martinez-Martin, A.P. Vargas, Independent validation of SCOPA-psychosocial and metric properties of the PDQ-39 Brazilian version, Mov. Disord. (2007). https://doi.org/10.1002/mds.21216.

[35] J.R. J., V. E., F. P., J. C., Validation of the Portuguese version of the 39-item Parkinson's disease questionnaire, Eur. J. Neurol. (2016). https://doi.org/http://dx.doi.org/10.1111/ene.13093.

[36] P. Martínez-Martín, B. Frades Payo, Quality of life in Parkinson's disease: validation study of the PDQ-39 Spanish version. The Grupo Centro for Study of Movement Disorders., J. Neurol. (1998). 
https://doi.org/10.1007/p100007737.

[37] S. C.T.R., S. G.M., J. R.D.G., Translation of the 39-item Parkinson's disease questionnaire to Filipino, Mov. Disord. (2015). https://doi.org/http://dx.doi.org/10.1002/mds.26295.

[38] D.M. Bushnell, M.L. Martin, Quality of life and Parkinson's disease: Translation and validation of the US Parkinson's Disease Questionnaire (PDQ-39), Qual. Life Res. (1999). https://doi.org/10.1023/A:1008979705027.

[39] Z. Katsarou, S. Bostantjopoulou, V. Peto, A. Alevriadou, G. Kiosseoglou, Quality of life in Parkinson's disease: Greek translation and validation of the Parkinson's disease questionnaire (PDQ39), Qual. Life Res. (2001). https://doi.org/10.1023/A:1016720400862.

[40] G. Galeoto, F. Colalelli, P. Massai, A. Berardi, M. Tofani, M. Pierantozzi, A. Servadio, A. Fabbrini, G. Fabbrini, Quality of life in Parkinson's disease: Italian validation of the Parkinson's Disease Questionnaire (PDQ-39-IT), Neurol. Sci. 39 (2018) 1903-1909. https://doi.org/10.1007/s10072-0183524-x.

[41] K.L. Tsang, I. Chi, S.L. Ho, V.W. Lou, T.M.C. Lee, L.W. Chu, Translation and validation of the standard Chinese version of PDQ-39: A quality-of-life measure for patients with Parkinson's disease, Mov. Disord. (2002). https://doi.org/10.1002/mds.10249.

[42] H.I. Ma, W.J. Hwang, M.J. Chen-Sea, Reliability and validity testing of a Chinese-translated version of the 39-item Parkinson's Disease Questionnaire (PDQ-39), Qual. Life Res. (2005). https://doi.org/10.1007/s11136-004-0687-0.

[43] D.Y. Kwon, J.W. Kim, H. Il Ma, T.B. Ahn, J. Cho, P.H. Lee, S.J. Chung, J.S. Kim, J.S. Baik, S.B. Koh, Translation and validation of the Korean version of the 39-item Parkinson's disease questionnaire, J. Clin. Neurol. (2013). https://doi.org/10.3988/jen.2013.9.1.26.

[44] Ü. Krikmann, P. Taba, T. Lai, T. Asser, Validation of an estonian version of the Parkinson's disease questionnaire (PDQ-39), Health Qual. Life Outcomes. (2008). https://doi.org/10.1186/1477-7525-623. 
[45] N. Luo, L.C.S. Tan, S.C. Li, L.K. Soh, J. Thumboo, Validity and reliability of the Chinese (Singapore) version of the Parkinson's Disease Questionnaire (PDQ-39), Qual. Life Res. (2005). https://doi.org/10.1007/s11136-004-2654-1.

[46] L.C.S. Tan, N. Luo, M. Nazri, S.C. Li, J. Thumboo, Validity and reliability of the PDQ-39 and the PDQ-8 in English-speaking Parkinson's disease patients in Singapore, Park. Relat. Disord. (2004). https://doi.org/10.1016/j.parkreldis.2004.05.007.

[47] W. Luo, X.H. Gui, B. Wang, W.Y. Zhang, Z.Y. Ouyang, Y. Guo, B.R. Zhang, M.P. Ding, Validity and reliability testing of the Chinese (mainland) version of the 39-item Parkinson's disease questionnaire (PDQ-39), J. Zhejiang Univ. Sci. B. (2010). https://doi.org/10.1631/jzus.B0900380.

[48] D. Morley, S. Dummett, L. Kelly, J. Dawson, C. Jenkinson, Evaluating the psychometric properties of an e-based version of the 39-item Parkinson's Disease Questionnaire, Health Qual. Life Outcomes. (2015). https://doi.org/10.1186/s12955-014-0193-1.

[49] J. Marinus, M. Visser, C. Jenkinson, A.M. Stiggelbout, Evaluation of the Dutch version of the Parkinson's Disease Questionnaire 39, Park. Relat. Disord. (2008). https://doi.org/10.1016/j.parkreldis.2007.05.005.

[50] L. Žiropada, E. Stefanova, A. Potrebić, V.S. Kostić, Quality of life in Serbian patients with Parkinson's disease, Qual. Life Res. (2009). https://doi.org/10.1007/s11136-009-9500-4.

[51] P. Martínez-Martín, M. Serrano-Dueñas, V. Vaca-Baquero, Psychometric characteristics of the Parkinson's disease questionnaire (PDQ-39) - Ecuadorian version, Park. Relat. Disord. (2005). https://doi.org/10.1016/j.parkreldis.2005.02.003.

[52] P. Auquier, C. Sapin, M. Ziegler, F. Tison, A. Destée, B. Dubois, M.P. Allicar, J.L. Thibault, C. Jenkinson, V. Peto, [Validation of the French language version of the Parkinson's Disease Questionnaire - PDQ-39]., Rev. Neurol. (Paris). (2002).

[53] K. Berger, S. Broll, J. Winkelmann, I. Heberlein, T. Müller, V. Ries, Untersuchung zur reliabilitat der deutschen version des PDQ-39: Ein krankheitsspezifischer fragebogen zur erfassung der lebensqualitat von Parkinson-patienten, Aktuelle Neurol. (1999). https://doi.org/10.1055/s-2007- 
1017628.

[54] J. Kohmoto, S. Ohbu, M. Nagaoka, Y. Suzukamo, T. Kihira, Y. Mizuno, Y.M. Ito, T. Yamaguchi, Y. Ohashi, S. Fukuhara, T. Kondo, Validation of the Japanese version of the Parkinson's Disease Questionnaire, Clin. Neurol. (2003).

[55] V. Peto, C. Jenkinson, R. Fitzpatrick, R. Greenhall, The development and validation of a short measure of functioning and well being for individuals with Parkinson's disease, Qual. Life Res. (1995). https://doi.org/10.1007/BF02260863.

[56] C. Jenkinson, R. Fitzpatrick, Cross-cultural evaluation of the short form 8-item Parkinson's Disease Questionnaire (PDQ-8): Results from America, Canada, Japan, Italy and Spain, Park. Relat. Disord. (2007). https://doi.org/10.1016/j.parkreldis.2006.06.006.

[57] T.T. Huang, H.Y. Hsu, B.H. Wang, K.H. Chen, Quality of life in Parkinson's disease patients: validation of the Short-Form Eight-item Parkinson's Disease Questionnaire (PDQ-8) in Taiwan., Qual. Life Res. (2011). https://doi.org/10.1007/s11136-010-9777-3.

[58] T. Kahraman, A. Genc, F. Soke, E. Goz, B. Donmez Colakoglu, P. Keskinoglu, Validity and Reliability of the Turkish Version of the 8-Item Parkinson's Disease Questionnaire, Noro Psikiyatr. Ars. (2017). https://doi.org/10.5152/npa.2017.19343.

[59] S.M. Fereshtehnejad, N. Naderi, A. Rahmani, G.A. Shahidi, A. Delbari, J. Lökk, Psychometric study of the Persian short-form eight-item Parkinson's disease questionnaire (PDQ-8) to evaluate health related quality of life (HRQoL), Health Qual. Life Outcomes. (2014). https://doi.org/10.1186/14777525-12-78.

[60] Z. Katsarou, S. Bostantjopoulou, V. Peto, A. Kafantari, E. Apostolidou, E. Peitsidou, Assessing quality of life in Parkinson's disease: Can a short-form questionnaire be useful?, Mov. Disord. (2004). https://doi.org/10.1002/mds.10678.

[61] T. Soulas, M. Storme, P. Martínez-Martín, M. Pichlak, J.M. Gurruchaga, S. Palfi, G. Fenelon, Assessing health-related quality of life with the SCOPA-PS in French individuals with Parkinson's disease having undergone DBS-STN: A validation study, Rev. Neurol. (Paris). (2016). 
https://doi.org/10.1016/j.neurol.2015.10.010.

[62] P. Martínez-Martín, E. Carroza-García, B. Frades-Payo, C. Rodríguez-Blázquez, M.J. Forjaz, J. De Pedro-Cuesta, Atributos psicométricos de la Scales for Outcomes in Parkinson’s DiseasePsychosocial (SCOPA-PS): Validación en España y revisión, Rev. Neurol. (2009). https://doi.org/10.33588/rn.4901.2009014.

[63] S.M. Fereshtehnejad, F. Farhadi, H. Hadizadeh, G.A. Shahidi, A. Delbari, J. Lökk, Cross-cultural validity, reliability, and psychometric properties of the persian version of the scales for outcomes in parkinson's disease-psychosocial questionnaire, Neurol. Res. Int. (2014). https://doi.org/10.1155/2014/260684.

[64] J. Virués-Ortega, F.J. Carod-Artal, M. Serrano-Dueñas, G. Ruiz-Galeano, G. Meza-Rojas, C. Velázquez, F. Micheli, P. Martínez-Martín, Cross-cultural validation of the Scales for Outcomes in Parkinson's Disease-Psychosocial questionnaire (SCOPA-PS) in four Latin American countries, Value Heal. (2009). https://doi.org/10.1111/j.1524-4733.2008.00436.x.

[65] J. Marinus, M. Visser, P. Martínez-Martín, J.J. Van Hilten, A.M. Stiggelbout, A short psychosocial questionnaire for patients with Parkinson's disease: The SCOPA-PS, J. Clin. Epidemiol. (2003). https://doi.org/10.1016/S0895-4356(02)00569-3.

[66] S. Goebel, E. Steinmann, B. Leplow, H.M. Mehdorn, Cross-cultural adaptation and psychometric properties of the SCOPA-Sleep - German version, Neurol. Sci. (2018). https://doi.org/10.1007/s10072-018-3397-z.

[67] Y.H. Sung, H.J. Kim, S.B. Koh, J.S. Kim, S.J. Kim, S.M. Cheon, J.W. Cho, Y.J. Kim, H. Il Ma, M.Y. Park, J.S. Baik, P.H. Lee, S.J. Chung, J.M. Kim, I.U. Song, H.J. Kim, J.Y. Kim, D.Y. Kwon, J.H. Lee, J.Y. Lee, J.S. Kim, J.Y. Yun, J.Y. Hong, M.J. Kim, J. Youn, J.S. Kim, E.S. Oh, H.J. Yang, W.T. Yoon, S. You, K.Y. Kwon, H.E. Park, S.Y. Lee, Y. Kim, H.T. Kim, T.B. Ahn, Validation of the Korean version of the scales for outcomes in Parkinson's Disease-Sleep, J. Korean Med. Sci. (2018). https://doi.org/10.3346/jkms.2018.33.e14.

[68] P. Hagell, A. Westergren, S. Janelidze, O. Hansson, The Swedish SCOPA-SLEEP for assessment of 
sleep disorders in Parkinson's disease and healthy controls, Qual. Life Res. (2016). https://doi.org/10.1007/s11136-016-1318-2.

[69] P. Martinez-Martin, M. Visser, C. Rodriguez-Blazquez, J. Marinus, K.R. Chaudhuri, J.J. van Hilten, E. Cubo-Delgado, M. Aguilar-Barberá, S. Escalante, A. Rojo, J. Campdelacreu, A. Bergareche, B. Frades, S. Arroyo, SCOPA-sleep and PDSS: Two scales for assessment of sleep disorder in Parkinson's disease, Mov. Disord. (2008). https://doi.org/10.1002/mds.22110.

[70] J. Marinus, M. Visser, J.J. Van Hilten, G.J. Lammers, A.M. Stiggelbout, Assessment of sleep and sleepiness in parkinson disease, Sleep. (2003). https://doi.org/10.1093/sleep/26.8.1049.

[71] C. Trenkwalder, R. Kohnen, B. Högl, V. Metta, F. Sixel-Döring, B. Frauscher, J. Hülsmann, P. Martinez-Martin, K.R. Chaudhuri, Parkinson's disease sleep scale-validation of the revised version PDSS-2, Mov. Disord. (2011). https://doi.org/10.1002/mds.23476.

[72] D. Arnaldi, C. Cordano, F. De Carli, J. Accardo, M. Ferrara, A. Picco, T. Tamburini, A. Brugnolo, G. Abbruzzese, F. Nobili, Parkinson's Disease Sleep Scale 2: application in an Italian population, Neurol. Sci. (2016). https://doi.org/10.1007/s10072-015-2409-5.

[73] K. Suzuki, M. Miyamoto, T. Miyamoto, M. Tatsumoto, Y. Watanabe, S. Suzuki, M. Iwanami, T. Sada, T. Kadowaki, A. Numao, C. Trenkwalder, K. Hirata, Nocturnal disturbances and restlessness in Parkinson's disease: Using the Japanese version of the Parkinson's disease sleep scale-2, J. Neurol. Sci. (2012). https://doi.org/10.1016/j.jns.2012.03.022.

[74] R.G. Brown, A. Dittner, L. Findley, S.C. Wessely, The Parkinson fatigue scale, Park. Relat. Disord. (2005). https://doi.org/10.1016/j.parkreldis.2004.07.007.

[75] E.A. Ozturk, B.G. Kocer, E. Umay, A. Cakci, Cross-cultural adaptation and psychometric evaluations of the Turkish version of Parkinson Fatigue Scale, Qual. Life Res. (2018). https://doi.org/10.1007/s11136-018-1907-3.

[76] R. Fu, S.S. Cui, J.J. Du, P. Huang, Y.C. He, C. Gao, X.G. Luo, S. Di Chen, Validation of the Parkinson Fatigue Scale in Chinese Parkinson's disease patients, Brain Behav. (2017). https://doi.org/10.1002/brb3.712. 
[77] I.E. Dagklis, E. Tsantaki, D. Kazis, V. Theodoridou, S. Papagiannopoulos, D. Ntantos, S. Bostantjopoulou, The Parkinson fatigue scale: an evaluation of its validity and reliability in Greek Parkinson's disease patients, Neurol. Sci. (2019). https://doi.org/10.1007/s10072-018-3695-5.

[78] P. Martinez-Martin, J.B. Wetmore, J.M. Arbelo, M.-J. Catalán, F. Valldeoriola, C. RodriguezBlazquez, $<$ p $>$ Validation study of the Parkinson\&rsquo;s Fatigue Scale in advanced Parkinson\&rsquo;s disease $</ \mathrm{p}>$, Patient Relat. Outcome Meas. (2019). https://doi.org/10.2147/prom.s196042.

[79] P. Hobson, A. Holden, J. Meara, Measuring the impact of Parkinson's disease with the Parkinson's Disease Quality of Life questionnaire, Age Ageing. (1999). https://doi.org/10.1093/ageing/28.4.341.

[80] M. Schulzer, E. Mak, S.M. Calne, The psychometric properties of the Parkinson's Impact Scale (PIMS) as a measure of quality of life in Parkinson's disease, Park. Relat. Disord. (2003). https://doi.org/10.1016/S1353-8020(03)00019-1.

[81] B. Van Hout, M.F. Janssen, Y.S. Feng, T. Kohlmann, J. Busschbach, D. Golicki, A. Lloyd, L. Scalone, P. Kind, A.S. Pickard, Interim scoring for the EQ-5D-5L: Mapping the EQ-5D-5L to EQ5D-3L value sets, Value Heal. (2012). https://doi.org/10.1016/j.jval.2012.02.008.

[82] R. Margis, K.C. Donis, S.V. Schönwald, C.R.M. Rieder, WHOQOL-OLD assessment of quality of life in elderly patients with Parkinson's disease: Influence of sleep and depressive symptoms, Rev. Bras. Psiquiatr. (2010). https://doi.org/10.1590/S1516-44462010005000008.

[83] C.J. Nowinski, A. Siderowf, T. Simuni, C. Wortman, C. Moy, D. Cella, Neuro-QoL health-related quality of life measurement system: Validation in Parkinson's disease, Mov. Disord. (2016). https://doi.org/10.1002/mds.26546.

[84] I. Cova, M.E. Di Battista, N. Vanacore, C.P. Papi, G. Alampi, A. Rubino, M. Valente, G. Meco, P. Contri, A. Di Pucchio, E. Lacorte, A. Priori, C. Mariani, S. Pomati, Validation of the Italian version of the Non Motor Symptoms Scale for Parkinson's disease, Park. Relat. Disord. (2017). https://doi.org/10.1016/j.parkreldis.2016.10.020.

[85] C. Rodriguez-Blazquez, M.J. Forjaz, B. Frades-Payo, J. De Pedro-Cuesta, P. Martinez-Martin, 
Independent validation of the scales for outcomes in Parkinson's disease-autonomic (SCOPA-AUT), Eur. J. Neurol. (2010). https://doi.org/10.1111/j.1468-1331.2009.02788.x.

[86] J.G. Diniz, A.C. da Silva, A.C. Nóbrega, Quality of life and swallowing questionnaire for individuals with Parkinson's disease: development and validation, Int. J. Lang. Commun. Disord. (2018). https://doi.org/10.1111/1460-6984.12395.

[87] C.A. Lohnes, G.M. Earhart, External validation of abbreviated versions of the activities-specific balance confidence scale in Parkinson's disease, Mov. Disord. (2010). https://doi.org/10.1002/mds.22924.

[88] S.B. Jonasson, M.H. Nilsson, J. Lexell, Psychometric properties of the original and short versions of the Falls Efficacy Scale-International (FES-I) in people with Parkinson's disease, Health Qual. Life Outcomes. (2017). https://doi.org/10.1186/s12955-017-0689-6.

[89] J.A.O. Baggio, M.B. Curtarelli, G.R. Rodrigues, V. Tumas, Validity of the Brazilian version of the freezing of gait questionnaire, Arq. Neuropsiquiatr. (2012). https://doi.org/10.1590/s0004$282 \times 2012000800008$.

[90] S. Krishnan, S. Justus, R. Meluveettil, R. Menon, S. Sarma, A. Kishore, Validity of Montreal Cognitive Assessment in Non-English speaking patients with Parkinson's disease, Neurol. India. (2015). https://doi.org/10.4103/0028-3886.152637.

[91] G. Santangelo, A. D’Iorio, F. Piscopo, S. Cuoco, K. Longo, M. Amboni, C. Baiano, D. Tafuri, M.T. Pellecchia, P. Barone, C. Vitale, Assessment of apathy minimising the effect of motor dysfunctions in Parkinson's disease: a validation study of the dimensional apathy scale, Qual. Life Res. (2017). https://doi.org/10.1007/s11136-017-1569-6. 


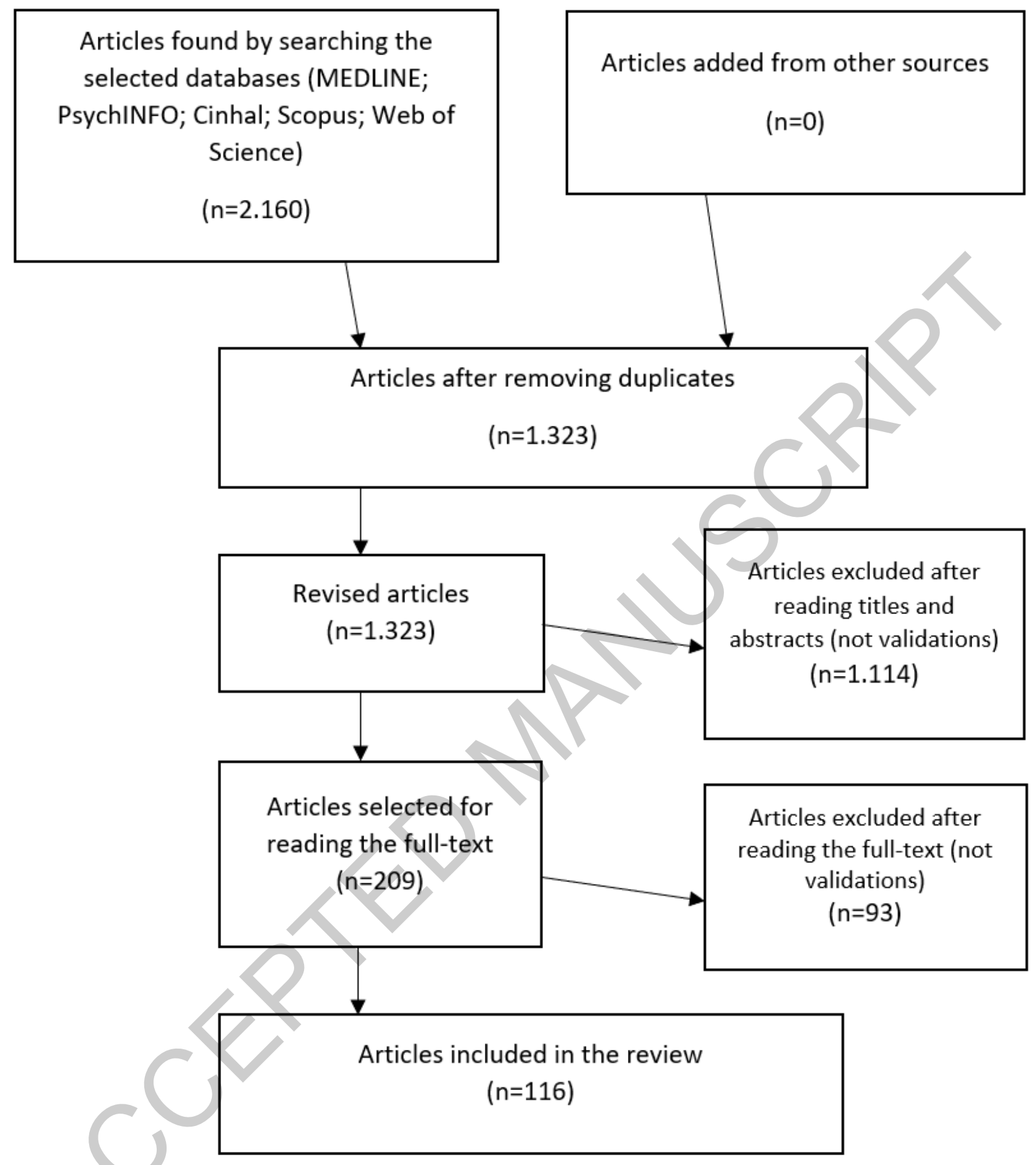

Figure 1 - Flowchart of included studies 
Table 1 - Outcome measures for quality of life in Parkinson's Disease

\begin{tabular}{|c|c|c|c|c|c|}
\hline Scale & First Author & Year & Scale & First Author & Year \\
\hline ABC & Lohnes & 2010 & NMSS & Martinez & 2009 \\
\hline BELA-P-k & Ortelli & 2017 & PDQ-39 & Peto & 1995 \\
\hline DAS & Santangelo & 2017 & PDQ-8 & Jenkinson & 2006 \\
\hline DextG & Vanbellingen & 2016 & PDQL & Hobson & 1999 \\
\hline D-FIS & Martinez & 2005 & PDSS & Martinez & 2004 \\
\hline DYPAGS & Cremèrs & 2012 & PDSS-2 & Trenkwalder & 2011 \\
\hline EC-PC & Ambrosio & 2016 & PFS & Fu & 2017 \\
\hline EQ-5D & Garcia & 2013 & PHQ-9 & Hortes & 2013 \\
\hline FES & Jonasson & 2014 & PIMS & Calne & 1995 \\
\hline FOG-Q & Baggio & 2012 & PROMIS & Baldini & 2017 \\
\hline FSS & Valderramas & 2012 & PSAS & Zhang & 2015 \\
\hline HADS & Marinus & 2002 & PsycH-Q & Shine & 2014 \\
\hline HAMD & Broen & 2014 & RDP & Defazio & 2015 \\
\hline HQL & Damiano & 2000 & SCOPA-Aut & Blazquez & 2009 \\
\hline KPS & Chaudhuri & 2015 & SCOPA-PS & Marinus & 2002 \\
\hline MFI & Elbers & 2012 & SCOPA-Sleep & Marinus & 2003 \\
\hline MoCA-TR & Ozdilek & 2014 & SDS & Chagas & 2009 \\
\hline MQoL-PD & Gofton & 2015 & SDQ & Yamamoto & 2011 \\
\hline Neuro-QoL & Martinez & 2004 & SEND-PD & Martinez & 2012 \\
\hline NHP & Hagell & 2003 & SWLS & Rosengren & 2014 \\
\hline & & & & & \\
\hline NMS & Li & 2014 & WHOQOL & Hirayama & 2007 \\
\hline & & & & & \\
\hline
\end{tabular}


Table 2 - 39 item- Parkinson's Disease Questionnaire (PDQ-39) publications and validation data

\begin{tabular}{|c|c|c|c|c|c|c|c|c|c|}
\hline \multicolumn{10}{|c|}{ PDQ-39 validation data } \\
\hline Author & Year & Language & Sample & Mean age & Gender (M/F) & Administration & Cronbach's Alpha & Test-retest & Construct validity \\
\hline Peto & 1995 & English & 227 & 70.3 & $57.4 / 42.6$ & Self-administred & 0.89 & - & SF-36 \\
\hline Jenkinson & 1997 & English & 227 & 70.30 & $57.4 / 42.6$ & Self-administred & 0.84 & - & $H \& Y$ \\
\hline Peto & 1998 & English & 359 & 71.4 & $57.4 / 42.5$ & Self-administred & 0.84 & - & SF-36 \\
\hline Martinez & 1998 & Spanish & 103 & 65.85 & $53.4 / 46.6$ & Self-administred & $0.63 / 0.94$ & $0.57 / 0.87$ & SF-36 \\
\hline Bushnell & 1999 & English (USA) & 139 & 69.5 & $52 / 48$ & Self-administred & $0.51 / 0.96$ & $0.86 / 0.96$ & SF-36 \\
\hline Berger & 1999 & German & 105 & 66 & $51.4 / 48.6$ & Self-administred & $0.55 / 0.96$ & - & SF-36 \\
\hline Katsarou & 2001 & Greek & 119 & 60.45 & $46.21 / 53.79$ & Self-administred & $0.71 / 0.94$ & - & UPDRS \\
\hline Auquier & 2002 & French & \multicolumn{7}{|c|}{ Full text not available } \\
\hline Tsang & 2002 & Chinese & 54 & 66.4 & $57.4 / 42.6$ & Interview & $0.54 / 0.90$ & - & - \\
\hline Kohmoto & 2003 & Japanese & \multicolumn{7}{|c|}{ Full text not available } \\
\hline Hagell & 2003 & Swedish & 71 & 69.1 & $62 / 38$ & Self-administred & $0.73 / 0.96$ & - & NHP \\
\hline Luo & 2005 & Chinese & 71 & 63.66 & $62 / 38$ & Self-administred & $0.84 / 0.88$ & $0.56 / 0.82$ & EQ-5D \\
\hline Ma & 2005 & Chinese & 73 & 69.02 & $57.5 / 42.5$ & Self-administred & $0.58 / 0.96$ & $0.71 / 0.95$ & SF-36 \\
\hline Martinez & 2005 & Spanish & 137 & 69.4 & $67.9 / 32.1$ & Self-administred & $0.33 / 0.96$ & - & UPDRS \\
\hline Carod-Artal & 2007 & Portuguese & 144 & 62 & $53.5 / 46.5$ & Interview & $0.61 / 0.85$ & 0.86 & SF-36 \\
\hline $\begin{array}{c}\text { Ülle } \\
\text { Krikmann }\end{array}$ & 2008 & Estonian & 81 & 66.9 & $67.9 / 32.1$ & Interview & $0.81 / 0.86$ & $>0.7$ & $\mathrm{H} \& \mathrm{Y}$ \\
\hline Marinus & 2008 & Danish & 177 & 65.2 & $56 / 44$ & Self-administred & $0.59 / 0.91$ & $0.40 / 0.75$ & SCOPA-PS, EQ-5D \\
\hline Ziropada & 2009 & Serbian & 102 & 58.4 & $53.92 / 46.08$ & Self-administred & 0.83 & - & SF-36 \\
\hline Nojomi & 2010 & Persian & 200 & 57.3 & $67.5 / 32.5$ & Self-administred & 0.93 & $0.47 / 0.90$ & SF-36 \\
\hline Luo & 2010 & Chinese & 63 & 65.0 & $58.7 / 41.3$ & Self-administred & $0.64 / 0.90$ & 0.94 & SF-36 \\
\hline Kwon & 2012 & Korean & 102 & 65.3 & $50.98 / 49.02$ & Interview & $0.58 / 0.80$ & - & UPDRS \\
\hline Zhang & 2012 & Chinese & 126 & 63.90 & $54.8 / 45.2$ & Self-administred & $0.457 / 0.887$ & - & SF-36 \\
\hline Park & 2013 & Korean & 93 & 65.13 & $41.9 / 58.1$ & Interview & $0.7 / 0.97$ & $0.69 / .094$ & $\mathrm{H} \& \mathrm{Y}$ \\
\hline Morley & 2015 & English & 118 & 63.48 & $55.93 / 44.07$ & Self-administred & $0.64 / 0.95$ & $0.34 / 0.90$ & - \\
\hline Ribeiro & 2017 & Portuguese & 100 & 65.8 & $42 / 58$ & Self-administred & $0.66 / 0.98$ & $0.49 / 0.96$ & SF-36 \\
\hline Suratos & 2018 & Filipino & 100 & 60.7 & $60 / 40$ & Self-administred & $0.845 / 0.0 .882$ & - & $\mathrm{H} \& \mathrm{Y}$ \\
\hline Galeoto & 2018 & Italian & 104 & 65.7 & $62 / 38$ & Self-administred & $0.69 / 0.92$ & $0.85 / 0.96$ & SF-36 \\
\hline
\end{tabular}


Table 3 - 8-Item Parkinosn's Disease Questionnaire (PDQ-8) publications and validation data.

\section{PDQ-8 validation data - Tab}

\begin{tabular}{|c|c|c|c|c|c|c|c|c|c|}
\hline Author & Year & Language & Sample & Mean age & Gender (M/F) & Administration & Cronbach's Alpha & Test-retest & Construct validity \\
\hline Martinez & 2003 & Spanish & 64 & 67.09 & $41.5 / 58.5$ & Self-administred & 0.842 & 0.83 & EQ-5D \\
\hline Katsarou & 2004 & Greek & 228 & 59.3 & $57.4 / 42.6$ & Self-administred & 0.72 & 0.90 & SF-36 \\
\hline Tan & 2004 & English & 88 & 63.1 & $70.5 / 29.5$ & Self-administred & $0.56 / 0.94$ & $0.67 / 0.87$ & $E Q-5 D$ \\
\hline Tan & 2007 & $\begin{array}{l}\text { English } \\
\text { Chinese }\end{array}$ & $\begin{array}{c}104 \\
79\end{array}$ & $\begin{array}{l}59.9 \\
62.5\end{array}$ & $\begin{array}{l}73.1 / 26.9 \\
63.3 / 36.7\end{array}$ & Self-administred & $\begin{array}{l}0.81 \\
0.87\end{array}$ & $\begin{array}{l}0.44 / 0.67 \\
0.57 / 0.68\end{array}$ & H\&Y, UPDRS \\
\hline Jenkinson & 2007 & English & 227 & 70 & $57 / 43$ & Self-administred & 0.84 & $>0.79$ & PDQ-39 \\
\hline Franchignoni & 2008 & Italian & 200 & 72 & $42.5 / 57.5$ & Self-administred & 0.72 & $0.24 / 0.59$ & H\&Y, UPDRS \\
\hline Huang & 2010 & Chinese & 100 & 62.04 & $56 / 44$ & Self-administred & 0.81 & - & PDQ-39 \\
\hline Dal bello-Haas & 2010 & English & 24 & 64.9 & $75 / 25$ & Self-administred & 0.72 & 0.82 & PDQ-39 \\
\hline Fereshtehnejad & 2014 & Persian & 114 & 61.4 & $78.1 / 21.9$ & Self-administred & 0.740 & 0.983 & PDQ-39 \\
\hline Chen & 2017 & Chinese & 283 & 57 & $58.7 / 41.3$ & Self-administred & 0.80 & $0.96 / 0.98$ & PDQ-39, H\&Y, UPDRS \\
\hline Kahraman & 2018 & Turkish & 83 & 68.3 & $50.6 / 49.4$ & Self-administred & 0.78 & 0.97 & SF-36 \\
\hline
\end{tabular}




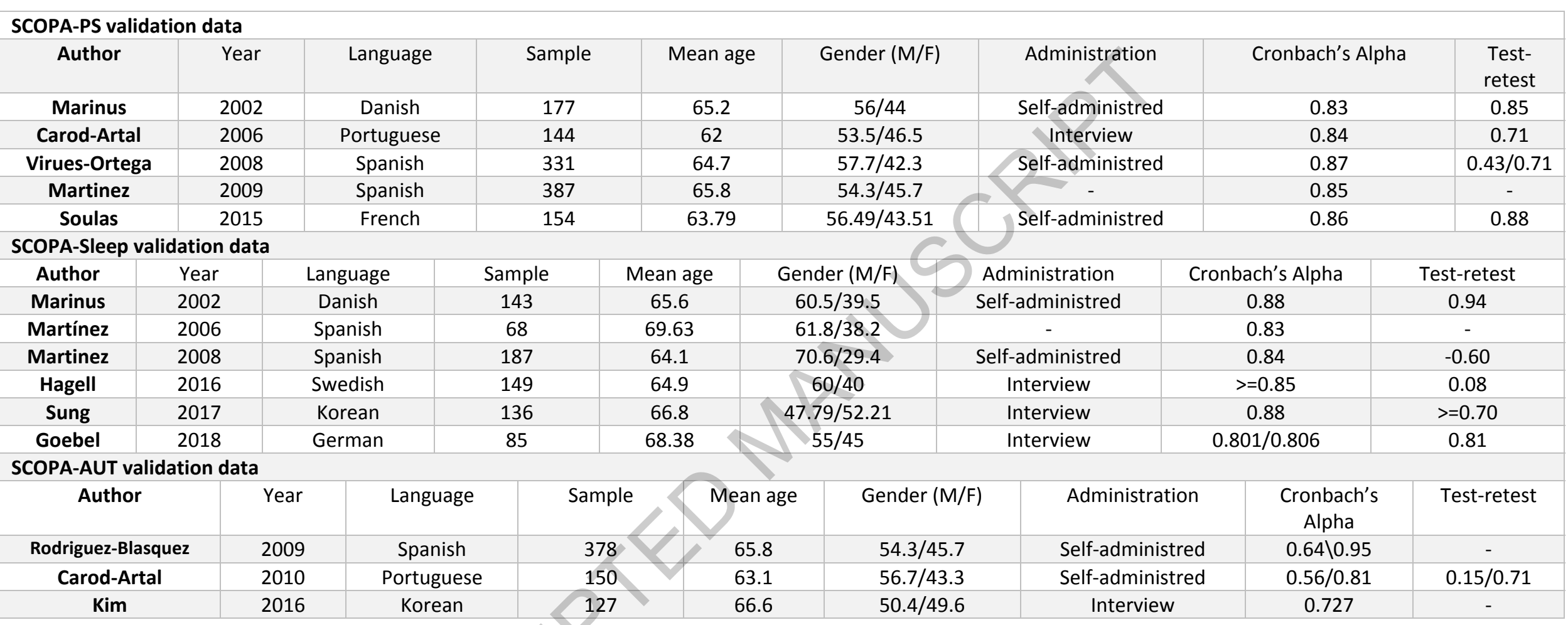


Table 5 - Parkinson's Disease Sleep Scale (PDSS) publications and validation data.

\begin{tabular}{|c|c|c|c|c|c|c|c|c|}
\hline \multicolumn{9}{|c|}{ PDSS-2 validation data } \\
\hline Author & Language & Sample & Mean age & Gender (M/F) & Administration & Cronbach's Alpha & Test-retest & Construct validity \\
\hline Kovacs & Ungarian & 537 & 66.8 & $58.3 / 41.7$ & Self-administred & 0.863 & - & Spearman's rho \\
\hline \multicolumn{9}{|c|}{ PDSS validation data } \\
\hline Author & Language & Sample & Mean age & Gender (M/F) & Administration & Cronbach's Alpha & Test-retest & Construct validity \\
\hline Martinez & Spanish & 100 & 61.75 & $51 / 49$ & Self-administred & 0.77 & 0.94 & Spearman's rho \\
\hline Martinez & Spanish, Danish & 187 & 64.1 & $70.6 / 29.4$ & Self-administred & 0.82 & -0.60 & Spearman's rho \\
\hline Martinez & Spanish & 399 & 67.81 & $56.89 / 43.11$ & Self-administred & 0.84 & 0.83 & Spearman's rho \\
\hline Suzuki & Japanese & 93 & 69.7 & $53.76 / 46.24$ & Self-administred & 0.86 & 0.90 & Spearman's rho \\
\hline Arnaldi & Italian & 123 & 70.1 & $61.78 / 38.22$ & Self-administred & 0.77 & 0.943 & Spearman's rho \\
\hline Trenkwalder & German & 113 & 65 & $58.4 / 41.6$ & Self-administred & 0.73 & 0.80 & Spearman's rho \\
\hline
\end{tabular}


Table 6 - Neuroquality of life (Neuro-qol), European Quality of Life Questionnaire 5-level version (EQ-5D-5L), Parkinson's Fatigue Scale (PFS) and Parkinson's Disease Quality of Life questionnaire (PDQL) publications and validation data.

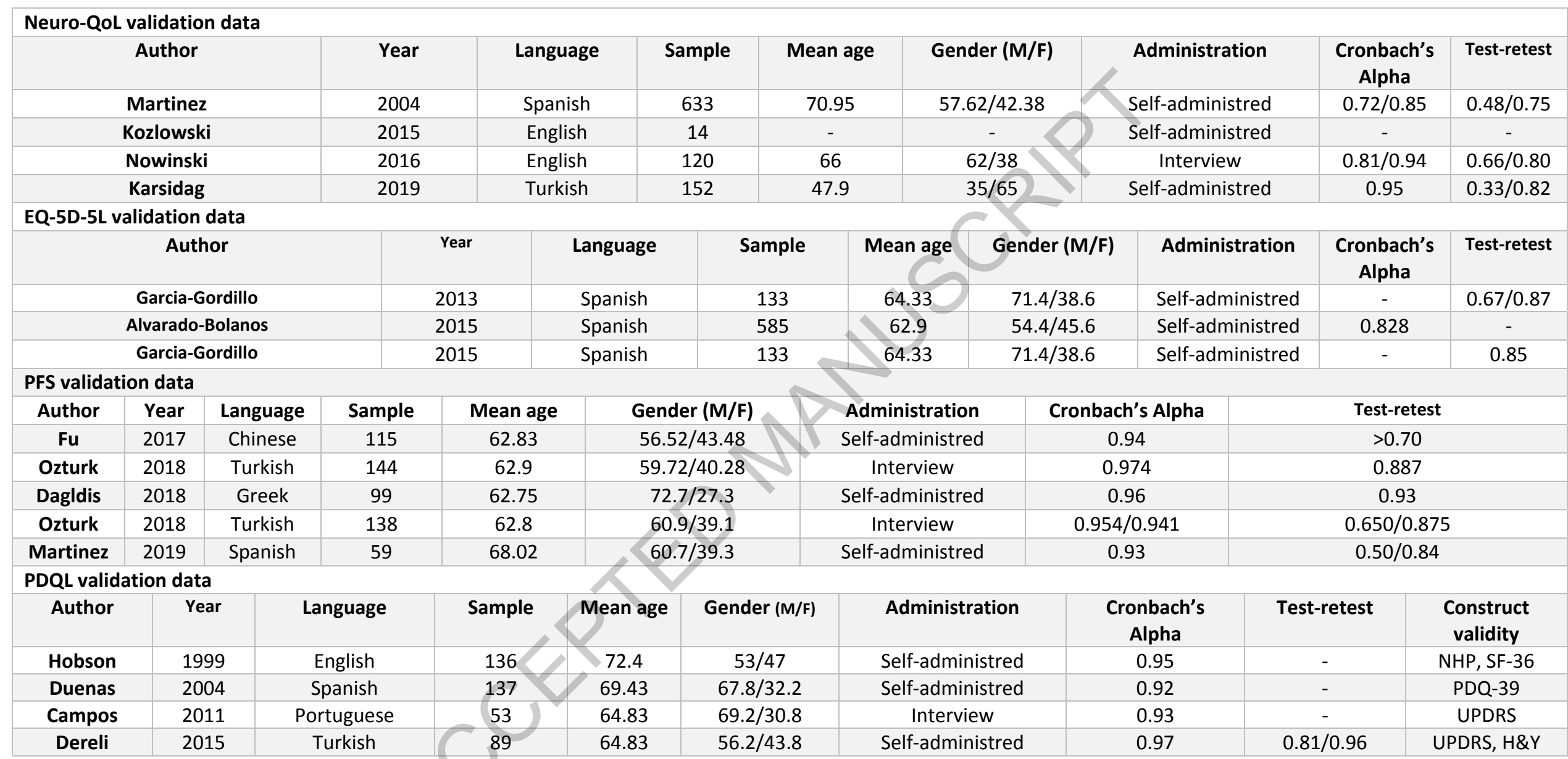

Table 7 - Quality assessment through the COSMIN checklist of included studies 


\begin{tabular}{|c|c|c|c|c|c|c|c|c|c|c|c|c|}
\hline \multicolumn{13}{|c|}{ Quality Assessment - ABC } \\
\hline Scale & Author & Year & $\begin{array}{c}\text { Internal } \\
\text { consistency }\end{array}$ & Reliability & $\begin{array}{l}\text { Measurement } \\
\text { error }\end{array}$ & $\begin{array}{l}\text { Content } \\
\text { validity }\end{array}$ & $\begin{array}{l}\text { Structure } \\
\text { Validity }\end{array}$ & $\begin{array}{l}\text { Hypothesis } \\
\text { Testing }\end{array}$ & $\begin{array}{c}\text { Cross- } \\
\text { cultural } \\
\text { Validation }\end{array}$ & $\begin{array}{l}\text { Criterion } \\
\text { Validity }\end{array}$ & Responsiveness & Interpretability \\
\hline $\mathrm{ABC}$ & Lohnes & 2010 & $x$ & $x$ & - & - & $x$ & - & - & - & - & - \\
\hline ABC, PDQ-8 & Haas & 2010 & $x$ & $x$ & $x$ & $x$ & $x$ & - & & $x$ & - & - \\
\hline FES, ABC & Jonasson & 2014 & $x$ & $x$ & $x$ & $x$ & $x$ & - & $x$ & - & $x$ & - \\
\hline \multicolumn{13}{|c|}{ Quality Assessment - D-FIS } \\
\hline Scale & Author & Year & $\begin{array}{c}\text { Internal } \\
\text { consistency }\end{array}$ & Reliability & $\begin{array}{l}\text { Measurement } \\
\text { error }\end{array}$ & $\begin{array}{l}\text { Content } \\
\text { validity }\end{array}$ & $\begin{array}{l}\text { Structure } \\
\text { Validity }\end{array}$ & $\begin{array}{c}\text { Hypothesis } \\
\text { Testing }\end{array}$ & $\begin{array}{l}\text { Cross- } \\
\text { cultural } \\
\text { Validation }\end{array}$ & $\begin{array}{l}\text { Criterion } \\
\text { Validity }\end{array}$ & Responsiveness & Interpretability \\
\hline D-FIS & Martinez & 2005 & $x$ & $x$ & $x$ & - & $x$ & $x$ & $x$ & - & $x$ & - \\
\hline D-FIS & Duenas & 2018 & $x$ & $x$ & $x$ & - & $x$ & & - & - & - & - \\
\hline \multicolumn{13}{|c|}{ Quality Assessment - EQ-5D } \\
\hline Scale & Author & Year & $\begin{array}{c}\text { Internal } \\
\text { consistency }\end{array}$ & Reliability & $\begin{array}{l}\text { Measurement } \\
\text { error }\end{array}$ & $\begin{array}{l}\text { Content } \\
\text { validity }\end{array}$ & $\begin{array}{l}\text { Structure } \\
\text { Validity }\end{array}$ & $\begin{array}{l}\text { Hypothesis } \\
\text { Testing }\end{array}$ & $\begin{array}{c}\text { Cross- } \\
\text { cultural } \\
\text { Validation }\end{array}$ & $\begin{array}{l}\text { Criterion } \\
\text { Validity }\end{array}$ & Responsiveness & Interpretability \\
\hline EQ-5D & Garcia & 2013 & - & $x$ & - & $x$ & $x$ & - & $x$ & - & $x$ & - \\
\hline EQ-5D & Alvarado & 2015 & $x$ & - & - & $x$ & $x$ & $x$ & $x$ & - & - & - \\
\hline EQ-5D & Garcia & 2015 & - & $x$ & - & $x$ & $x$ & - & - & - & $x$ & - \\
\hline \multicolumn{13}{|c|}{ Quality Assessment - FES } \\
\hline Scale & Author & Year & $\begin{array}{c}\text { Internal } \\
\text { consistency }\end{array}$ & Reliability & $\begin{array}{l}\text { Measurement } \\
\text { error }\end{array}$ & $\begin{array}{l}\text { Content } \\
\text { validity }\end{array}$ & $\begin{array}{l}\text { Structure } \\
\text { Validity }\end{array}$ & $\begin{array}{l}\text { Hypothesis } \\
\text { Testing }\end{array}$ & $\begin{array}{c}\text { Cross- } \\
\text { cultural } \\
\text { Validation }\end{array}$ & $\begin{array}{l}\text { Criterion } \\
\text { Validity }\end{array}$ & Responsiveness & Interpretability \\
\hline FES, ABC & Jonasson & 2014 & $x$ & & $x$ & $x$ & $x$ & - & $x$ & - & $x$ & - \\
\hline FES & Jonasson & 2017 & $x$ & & $x$ & - & $x$ & - & - & - & - & - \\
\hline \multicolumn{13}{|c|}{ Quality Assessment - MoCA-TR } \\
\hline Scale & Author & Year & $\begin{array}{c}\text { Internal } \\
\text { consistency }\end{array}$ & Reliability & $\begin{array}{l}\text { Measurement } \\
\text { error }\end{array}$ & $\begin{array}{l}\text { Content } \\
\text { validity }\end{array}$ & $\begin{array}{l}\text { Structure } \\
\text { Validity }\end{array}$ & $\begin{array}{l}\text { Hypothesis } \\
\text { Testing }\end{array}$ & $\begin{array}{c}\text { Cross- } \\
\text { cultural } \\
\text { Validation }\end{array}$ & $\begin{array}{l}\text { Criterion } \\
\text { Validity }\end{array}$ & Responsiveness & Interpretability \\
\hline MoCA-TR & Krishnan & 2015 & $x$ & $x$ & - & - & $x$ & - & $x$ & - & - & - \\
\hline MoCA-TR & Ozdilek & 2014 & $x$ & $x$ & - & - & $x$ & - & - & $x$ & $x$ & - \\
\hline \multicolumn{13}{|c|}{ Quality Assessment - Neuro QoL } \\
\hline Scale & Author & Year & $\begin{array}{l}\text { Internal } \\
\text { consistency }\end{array}$ & Reliability & $\begin{array}{l}\text { Measurement } \\
\text { error }\end{array}$ & $\begin{array}{l}\text { Content } \\
\text { validity }\end{array}$ & $\begin{array}{l}\text { Structure } \\
\text { Validity }\end{array}$ & $\begin{array}{l}\text { Hypothesis } \\
\text { Testing }\end{array}$ & $\begin{array}{l}\text { Cross- } \\
\text { cultural }\end{array}$ & $\begin{array}{l}\text { Criterion } \\
\text { Validity }\end{array}$ & Responsiveness & Interpretability \\
\hline
\end{tabular}




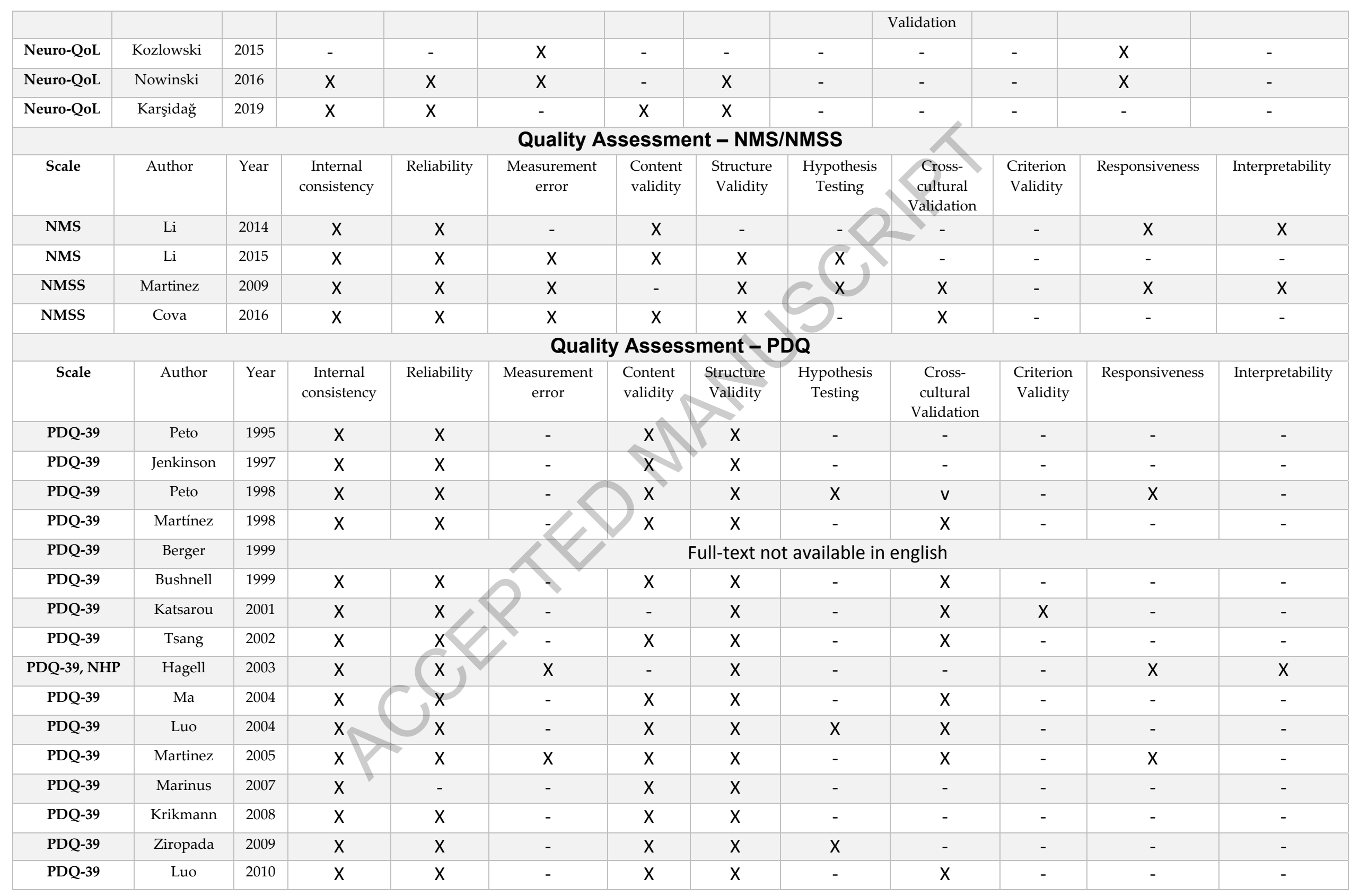




\begin{tabular}{|c|c|c|c|c|c|c|c|c|c|c|c|c|}
\hline PDQ-39 & Nojomi & 2010 & $x$ & $x$ & - & $x$ & $x$ & $x$ & $x$ & - & - & - \\
\hline PDQ-39 & Zhang & 2011 & $x$ & $x$ & - & $x$ & $x$ & - & $x$ & - & - & - \\
\hline PDQ-39 & Kwon & 2012 & $x$ & $x$ & - & $x$ & $x$ & - & $x$ & - & - & - \\
\hline $\begin{array}{l}\text { PDQ-39, } \\
\text { NMSS }\end{array}$ & Carod-Artal & 2012 & $x$ & $x$ & $x$ & - & $x$ & $x$ & $x$ & - & - & - \\
\hline PDQ-39 & Park & 2013 & $x$ & $x$ & - & $x$ & $x$ & - & & $x$ & - & - \\
\hline PDQ-39 & Morley & 2015 & $x$ & $x$ & - & $x$ & $x$ & - & - & - & - & - \\
\hline PDQ-39 & Ribeiro & 2017 & $x$ & $x$ & - & $x$ & $x$ & - & $x$ & $x$ & - & - \\
\hline PDQ-39 & Suratos & 2018 & $x$ & $x$ & - & - & $x$ & $x$ & $x$ & - & - & - \\
\hline PDQ-39 & Galeoto & 2018 & $x$ & $x$ & - & $x$ & $x$ & - & $x$ & - & - & - \\
\hline \multicolumn{13}{|c|}{ Quality Assessment - PDQ-8 } \\
\hline Scale & Author & Year & $\begin{array}{l}\text { Internal } \\
\text { consistency }\end{array}$ & Reliability & $\begin{array}{l}\text { Measurement } \\
\text { error }\end{array}$ & $\begin{array}{l}\text { Content } \\
\text { validity }\end{array}$ & $\begin{array}{l}\text { Structure } \\
\text { Validity }\end{array}$ & $\begin{array}{l}\text { Hypothesi } \\
\text { s Testing }\end{array}$ & $\begin{array}{l}\text { Cross-cultural } \\
\text { Validation }\end{array}$ & $\begin{array}{l}\text { Criterion } \\
\text { Validity }\end{array}$ & Responsiveness & Interpretability \\
\hline $\begin{array}{l}\text { PDQ-8, } \\
\text { Neuro-QoL }\end{array}$ & Martinez & 2004 & $x$ & $x$ & - & $x$ & $x$ & - & - & - & - & - \\
\hline PDQ-8 & Kim & 2004 & $x$ & $x$ & - & $x$ & $x$ & $x$ & $x$ & - & - & - \\
\hline PDQ-8 & Jenkinson & 2006 & $x$ & $x$ & - & $x$ & $x$ & - & $x$ & - & - & - \\
\hline PDQ-8 & Jenkinson & 2007 & $x$ & $x$ & - & $x$ & $x$ & - & - & $x$ & - & - \\
\hline PDQ-8 & Tan & 2007 & $x$ & $x$ & $x$ & - & $x$ & $x$ & $x$ & - & - & - \\
\hline PDQ-8 & Franchignoni & 2008 & $x$ & $x$ & $X$ & $x$ & $x$ & - & - & - & - & - \\
\hline PDQ-8 & Huang & 2010 & $x$ & $x$ & & $x$ & $x$ & - & - & $x$ & - & - \\
\hline PDQ-8 & Fereshtehnejad & 2014 & $x$ & $x$ & - & $x$ & $x$ & $x$ & $x$ & $x$ & - & - \\
\hline PDQ-8 & Chen & 2017 & $x$ & $v$ & - & $x$ & $x$ & $x$ & $x$ & $x$ & - & - \\
\hline PDQ-8 & Kahraman & 2018 & $x$ & & - & $x$ & $x$ & $x$ & $x$ & - & - & - \\
\hline \multicolumn{13}{|c|}{ Quality Assessment - PDQL } \\
\hline Scale & Author & Year & $\begin{array}{c}\text { Internal } \\
\text { consistency }\end{array}$ & Reliability & $\begin{array}{l}\text { Measurement } \\
\text { error }\end{array}$ & $\begin{array}{l}\text { Content } \\
\text { validity }\end{array}$ & $\begin{array}{l}\text { Structure } \\
\text { Validity }\end{array}$ & $\begin{array}{l}\text { Hypothesi } \\
\text { s Testing }\end{array}$ & $\begin{array}{l}\text { Cross-cultural } \\
\text { Validation }\end{array}$ & $\begin{array}{l}\text { Criterion } \\
\text { Validity }\end{array}$ & Responsiveness & Interpretability \\
\hline PDQL & Hobson & 1999 & $x$ & - & - & $x$ & & $x$ & $x$ & - & - & - \\
\hline PDQL & Duenas & 2004 & $x$ & - & $x$ & $x$ & $x$ & $x$ & $x$ & - & $x$ & - \\
\hline PDQL & Campos & 2011 & $x$ & $x$ & - & $x$ & $x$ & $x$ & $x$ & - & - & - \\
\hline PDQL & Dereli & 2015 & $x$ & $x$ & - & $x$ & $\mathrm{X}$ & - & $x$ & - & - & - \\
\hline \multicolumn{13}{|c|}{ Quality Assessment - PDSS/PDSS-2 } \\
\hline
\end{tabular}




\begin{tabular}{|c|c|c|c|c|c|c|c|c|c|c|c|c|}
\hline Scale & Author & Year & $\begin{array}{c}\text { Internal } \\
\text { consistency }\end{array}$ & Reliability & $\begin{array}{l}\text { Measurement } \\
\text { error }\end{array}$ & $\begin{array}{l}\text { Content } \\
\text { validity }\end{array}$ & $\begin{array}{l}\text { Structure } \\
\text { Validity }\end{array}$ & $\begin{array}{l}\text { Hypothesi } \\
\text { s Testing }\end{array}$ & $\begin{array}{l}\text { Cross-cultural } \\
\text { Validation }\end{array}$ & $\begin{array}{l}\text { Criterion } \\
\text { Validity }\end{array}$ & Responsiveness & Interpretability \\
\hline PDSS & Martinez & 2004 & $\mathrm{x}$ & $x$ & $x$ & - & $x$ & - & - & - & - & - \\
\hline PDSS-2 & Trenkwalder & 2011 & $x$ & $x$ & $x$ & $x$ & $x$ & - & $x$ & - & - & - \\
\hline PDSS-2 & Suzuki & 2012 & $x$ & $x$ & - & $x$ & $x$ & - & $x$ & - & - & - \\
\hline PDSS-2 & Arnaldi & 2015 & $x$ & $x$ & $x$ & - & $x$ & - & $x$ & - & - & - \\
\hline PDSS-2 & Kovacs & 2016 & $x$ & $x$ & - & $x$ & $x$ & $x$ & $x$ & - & $x$ & - \\
\hline PDSS-2 & Martinez & 2019 & $x$ & $x$ & $x$ & $x$ & $x$ & & $x$ & - & - & - \\
\hline \multicolumn{13}{|c|}{ Quality Assessment - PFS } \\
\hline Scale & Author & Year & $\begin{array}{c}\text { Internal } \\
\text { consistency }\end{array}$ & Reliability & $\begin{array}{l}\text { Measurement } \\
\text { error }\end{array}$ & $\begin{array}{l}\text { Content } \\
\text { validity }\end{array}$ & $\begin{array}{l}\text { Structure } \\
\text { Validity }\end{array}$ & $\begin{array}{l}\text { Hypothesi } \\
\text { s Testing }\end{array}$ & $\begin{array}{l}\text { Cross-cultural } \\
\text { Validation }\end{array}$ & $\begin{array}{l}\text { Criterion } \\
\text { Validity }\end{array}$ & Responsiveness & Interpretability \\
\hline PFS & $\mathrm{Fu}$ & 2017 & $\mathrm{x}$ & $x$ & - & X & $\mathrm{X}$ & - & $x$ & - & - & - \\
\hline PFS & Ozturk & 2018 & $x$ & $x$ & $x$ & $x$ & & $x$ & $x$ & - & - & - \\
\hline PFS & Daglkis & 2018 & $x$ & $x$ & - & $x$ & 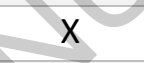 & - & $x$ & - & - & - \\
\hline PFS & Ozturk & 2018 & $x$ & $x$ & - & $x$ & $x$ & - & $x$ & - & - & - \\
\hline PFS & Martinez & 2019 & $x$ & $x$ & $x$ & $x$ & $x$ & - & - & - & $x$ & - \\
\hline \multicolumn{13}{|c|}{ Quality Assessment - PIMS } \\
\hline Scale & Author & Year & $\begin{array}{l}\text { Internal } \\
\text { consistency }\end{array}$ & Reliability & Measureme & $\begin{array}{l}\text { Content } \\
\text { validity }\end{array}$ & $\begin{array}{l}\text { Structure } \\
\text { Validity }\end{array}$ & $\begin{array}{l}\text { Hypothesi } \\
\text { s Testing }\end{array}$ & $\begin{array}{l}\text { Cross-cultural } \\
\text { Validation }\end{array}$ & $\begin{array}{l}\text { Criterion } \\
\text { Validity }\end{array}$ & Responsiveness & Interpretability \\
\hline PIMS & Calne & 1995 & $\mathrm{x}$ & $x$ & & $x$ & $\mathrm{X}$ & - & - & - & - & - \\
\hline PIMS & Schulzer & 2002 & $x$ & $x$ & & - & $x$ & - & - & - & $x$ & - \\
\hline PIMS & Duenas & 2007 & $x$ & $x$ & - & - & $x$ & - & $x$ & - & - & - \\
\hline \multicolumn{13}{|c|}{ Quality Assessment - SCOPA-Aut,PS,Sleep } \\
\hline Scale & Author & Year & $\begin{array}{c}\text { Internal } \\
\text { consistency }\end{array}$ & Reliability & $\begin{array}{l}\text { Measurement } \\
\text { error }\end{array}$ & $\begin{array}{l}\text { Content } \\
\text { validity }\end{array}$ & $\begin{array}{l}\text { Structure } \\
\text { Validity }\end{array}$ & $\begin{array}{l}\text { Hypothesi } \\
\text { s Testing }\end{array}$ & $\begin{array}{l}\text { Cross-cultural } \\
\text { Validation }\end{array}$ & $\begin{array}{l}\text { Criterion } \\
\text { Validity }\end{array}$ & Responsiveness & Interpretability \\
\hline SCOPA-Aut & Blazquez & 2009 & $\mathrm{x}$ & $x$ & $x$ & - & $x$ & - & $x$ & - & - & - \\
\hline SCOPA-Aut & Carod-Artal & 2010 & $x$ & $x$ & $x$ & $x$ & $x$ & $x$ & $x$ & - & - & - \\
\hline SCOPA-Aut & Kim & 2016 & $x$ & $x$ & - & - & $x$ & - & $x$ & - & - & - \\
\hline SCOPA-PS & Marinus & 2002 & $x$ & $x$ & - & $x$ & $x$ & - & - & - & - & - \\
\hline SCOPA-PS & Carod-Artal & 2006 & $x$ & $x$ & $x$ & $x$ & $x$ & $x$ & - & - & - & - \\
\hline SCOPA-PS & Ortega & 2008 & $x$ & - & $x$ & $x$ & $x$ & $x$ & $x$ & - & - & - \\
\hline SCOPA-PS & Martínez & 2009 & $x$ & - & $x$ & $x$ & $x$ & - & - & - & - & - \\
\hline
\end{tabular}




\begin{tabular}{|c|c|c|c|c|c|c|c|c|c|c|c|c|}
\hline SCOPA-PS & Soulas & 2015 & $x$ & $x$ & $x$ & - & $x$ & - & - & - & - & - \\
\hline $\begin{array}{l}\text { SCOPA- } \\
\text { Sleep }\end{array}$ & Marinus & 2003 & $x$ & $x$ & - & $x$ & $x$ & - & - & - & - & - \\
\hline $\begin{array}{l}\text { SCOPA- } \\
\text { Sleep }\end{array}$ & Martinez & 2006 & $x$ & - & $x$ & $x$ & $x$ & - & - & - & - & - \\
\hline $\begin{array}{l}\text { SCOPA- } \\
\text { Sleep, PDSS }\end{array}$ & Martinez & 2008 & $x$ & $x$ & $x$ & - & $x$ & - & $x$ & - & $x$ & - \\
\hline $\begin{array}{l}\text { SCOPA- } \\
\text { Sleep }\end{array}$ & Hagell & 2016 & $x$ & $x$ & $x$ & $x$ & $X$ & $x$ & $x$ & - & - & - \\
\hline $\begin{array}{l}\text { SCOPA- } \\
\text { Sleep }\end{array}$ & Sung & 2017 & $x$ & $x$ & - & $x$ & $x$ & & $x$ & - & - & - \\
\hline $\begin{array}{l}\text { SCOPA- } \\
\text { Sleep }\end{array}$ & Goebel & 2018 & $x$ & $x$ & - & $x$ & $x$ & $X$ & $x$ & - & - & - \\
\hline \multicolumn{13}{|c|}{ Quality Assessment - SDQ } \\
\hline Scale & Author & Year & $\begin{array}{c}\text { Internal } \\
\text { consistency }\end{array}$ & Reliability & $\begin{array}{c}\text { Measurement } \\
\text { error }\end{array}$ & $\begin{array}{l}\text { Content } \\
\text { validity }\end{array}$ & $\begin{array}{l}\text { Structure } \\
\text { Validity }\end{array}$ & $\begin{array}{l}\text { Hypothesi } \\
\text { s Testing }\end{array}$ & $\begin{array}{l}\text { Cross-cultural } \\
\text { Validation }\end{array}$ & $\begin{array}{l}\text { Criterion } \\
\text { Validity }\end{array}$ & Responsiveness & Interpretability \\
\hline SDQ & Yamamoto & 2011 & $x$ & $x$ & - & $x$ & - & - & $x$ & - & $x$ & - \\
\hline SDQ & Rajaei & 2014 & $x$ & $x$ & - & $x$ & - & - & $x$ & - & $x$ & - \\
\hline SDQ & Diniz & 2018 & $x$ & $\mathrm{X}$ & - & $x$ & $x$ & - & - & - & - & - \\
\hline \multicolumn{13}{|c|}{ Quality Assessment - SWLS } \\
\hline Scale & Author & Year & $\begin{array}{c}\text { Internal } \\
\text { consistency }\end{array}$ & Reliability & $\begin{array}{c}\text { Measurement } \\
\text { error }\end{array}$ & $\begin{array}{l}\text { Content } \\
\text { validity }\end{array}$ & $\begin{array}{l}\text { Structure } \\
\text { Validity }\end{array}$ & $\begin{array}{l}\text { Hypothesi } \\
\text { s Testing }\end{array}$ & $\begin{array}{l}\text { Cross-cultural } \\
\text { Validation }\end{array}$ & $\begin{array}{l}\text { Criterion } \\
\text { Validity }\end{array}$ & Responsiveness & Interpretability \\
\hline SWLS & Rosengren & 2014 & $\mathrm{X}$ & $x$ & & - & $x$ & - & - & - & - & - \\
\hline SWLS & Carrasco & 2014 & $x$ & - & $x$ & - & $x$ & - & $x$ & - & - & - \\
\hline \multicolumn{13}{|c|}{ Quality Assessment - WHOQOL } \\
\hline Scale & Author & Year & $\begin{array}{c}\text { Internal } \\
\text { consistency }\end{array}$ & Reliability & $\begin{array}{c}\begin{array}{c}\text { Measurement } \\
\text { error }\end{array} \\
\text {. }\end{array}$ & $\begin{array}{l}\text { Content } \\
\text { validity }\end{array}$ & $\begin{array}{l}\text { Structure } \\
\text { Validity }\end{array}$ & $\begin{array}{l}\text { Hypothesi } \\
\text { s Testing }\end{array}$ & $\begin{array}{l}\text { Cross-cultural } \\
\text { Validation }\end{array}$ & $\begin{array}{l}\text { Criterion } \\
\text { Validity }\end{array}$ & Responsiveness & Interpretability \\
\hline WHOQOL & Hirayama & 2007 & $\mathrm{x}$ & & - & $x$ & $x$ & - & $x$ & - & - & - \\
\hline WHOQOL & Margis & 2009 & - & - & - & - & - & - & - & - & - & - \\
\hline
\end{tabular}

